Paideusis

\title{
One More Span in the Bridge: A Rejoinder to Michael Apple, Ulf Lundgren, and John White
}

\section{Attila Horvath}

Volume 2, Number 2, 1989

URI: https://id.erudit.org/iderudit/1073415ar

DOI: https://doi.org/10.7202/1073415ar

See table of contents

Publisher(s)

Canadian Philosophy of Education Society

\section{ISSN}

0838-4517 (print)

1916-0348 (digital)

Explore this journal

Cite this article

Horvath, A. (1989). One More Span in the Bridge: A Rejoinder to Michael Apple, Ulf Lundgren, and John White. Paideusis, 2(2), 19-20.

https://doi.org/10.7202/1073415ar 


\title{
One More Span in the Bridge
}

\author{
A Rejoinder to Michael Apple, Ulf Lundgren, and John \\ White
}

\section{Attila Horvath National Institute of Education, Hungary}

I agree with the critical tone that characterized all three replies. It is indeed simplistic to split the world into East and West. It is even more simplistic to put one label on Western educational philosophy than it is to describe East European Marxist theory of education as one homogeneous system of thought. My attempt was to find a pair of theoretical archstones without which the philosophies in question cannot stand. In my view, these key concepts are rationality in British-American philosophy of education and communalism in Eastern European Marxism. Authors may devote more or less attention to these basics, but they can hardly avoid using them. At least, on our scene, Marxism has been far from monolithic since the late 1960s when Hungarian educational philosophy got the boost from Western Marxism. But Professor White may well be right when he says that recent British educational philosophy is more influenced by continental thinkers, even to the extent that they turn away from the questions of rationality. My ignorance of this development shows only the need for greater exchange between us.

The lines I drew sketched the extremes, but they do not have to. Certainly, we should not try to build a bridge where the gap is widest. When I called for a relativist approach - or, as Professor Apple put it, more flexible thinking, I excluded the possibility of a discourse between the two dichotomies. I might have exaggerated these opposites, but it would be equally big mistake to deny that they exist at all. As a good theorist, I had to learn this in practice! When organizing our conference last year which aimed to bring together philosophers of education from both East and West, we invited the orthodox rationalist, anti-Communist wing as well as experts from countries which have not yet been touched by "glasnost". Neither party even answered. This also proves the point raised by Professor Apple that differences in views are sometimes greater within than between the East and West camps.

There are, however, a few points which I do not share with my critics. The most important is that they treat Marxism as a single philosophy that appears in both Eastern and Western hemispheres. I have two problems with this approach. First, Marxism in the West is not only a far cry from that in the East (as Professor Apple points out in his first footnote), but it is also in a different power 
position in its political arena and, therefore, performs different tasks in society. Second, Marxism as such is inappropriate for establishing a practical pedagogy because it deals only with macro-systems. Bowles and Gintis in the U.S., Michael Young in Britain, Bourdieu in France or Michael Apple himself are not philosophers. They use Marxist (or analogous) methodology as a vehicle for deep and penetrating social criticism. The function of Marxism in the West is to be in opposition, to try to check the power of the state and institutions. They do not offer programs to be realized. It is not accidental that Dewey, A.S. Neil, and Rudolf Steiner were philosophers and founded real schools with real children. I know no Marxist philosophers in the West of this kind. (This state of affairs is quite contrary to Marx's view that theory is the practice of philosophy and the philosophy of practice.)

Actually, our experience with Marxism gaining power created total perplexity: what should a Marxist school look like? In forty years, nobody has found an answer to this question and not just because the political atmosphere was oppressive. Pedagogy cannot be derived from Marx's theories. The closest we got to a solution was to outline a Marxist anthropology along the lines suggested by Gramsci and Lukacs. In the meantime, the practical theory of schooling became groundless and subject to the whims of politics. Analytical thinking, as Professor Lundgren suggest, may help us to construe a new framework.

In the West, Marxism provides a counterbalance to the ruling power. In the East, alternative approaches should provide counterweights to the state monopoly in education. In our part of the world, Marxism cannot fulfil a power-checking role. The new, authentic Marxist movement in the early 1970s in Hungary yielded only criticism - paradoxically, Marxist criticism of Marxism. This is where it is best. We need criticism, both Marxist and analytical, but not only in books. The praxis of alternative schools could be our best weapon in fighting militant, state-party Marxism. In the West, Marxism offers you insight into the seemingly just democracies. Analytical thinking and pragmatism may give us tools for greater clarity of thought and the means to focus on schools and children instead of grand philosophy. 